\title{
Law, Public Policy and Mental Health in the Workplace -
}

\author{
INVITED ESSAY
}

Katherine Lippel LLL, LLm, Frsc

Canada Research Chair in Occupational Health and Safety Law

University of Ottawa

$\propto$

\begin{abstract}
The first part of this article describes regulatory interventions, drawn from different Canadian jurisdictions, designed to reduce worker exposure to psychosocial hazards, including occupational violence, and to protect workers' mental health. It also addresses legislative provisions providing workers' compensation for mental health problems and regulatory provisions supporting the return to work of those who have been absent from work because of work-related mental health problems. The second part of the article, relying on illustrations from case law in which workers' compensation claims for mental health problems have been accepted, examines ways in which law and policy can actually contribute directly or indirectly to behaviours that may lead to increasing illness and disability associated with mental health problems.
\end{abstract}

INTERNATIONALLY, OCCUPATIONAL PSYCHOsocial risk factors have become the focus of increasing attention in recent years. The World Health Organization's Plan of Action, endorsed by the World Health Assembly in May 2007, included the following as its 11th recommendation: "The assessment and management of health risks at the workplace should be improved by defining essential interventions for prevention and control of mechanical, physical, chemical, biological and psychosocial risks in the working environment. Such measures include also integrated management of ... health-impact assessment of new technologies, work processes...."

The European union has, for some time, 
acknowledged the importance of addressing psychosocial hazards in the workplace and it has taken a variety of initiatives in this regard, in terms of both research on policy (European Agency for Safety and Health at Work 2007) and policy initiatives to encourage member states to address stressful working conditions, their prevention and their consequences for the health of workers (Leka et al. 2010). The European Agency for Safety and Health at Work, in a Delphi study involving experts on occupational health hazards, identified the following as the top 10 emerging psychosocial hazards: precarious contracts in the context of unstable labour markets; increased workers' vulnerability in the context of globalization; new forms of employment contracts; feelings of job insecurity; an aging workforce; long working hours; work intensification; lean production and outsourcing; high emotional demands at work; and a poor work-life balance (European Agency for Safety and Health at Work 2007: 26). The same report suggests action plans, including ideas for policy recommendations designed to address not only the 10 emerging hazards but other psychosocial hazards, such as occupational violence, that are known to lead to adverse health outcomes.

Canadian studies have looked at the role of some of these hazards in the development of adverse health effects. Precarious employment, including insecure employment in the context of restructuring (Quinlan, 2007) and non-standard work contracts (Quinlan et al. 2001) are known to undermine the cohesion of work teams, reducing social support while increasing both workload and work demands of those on the same shift who are not employed under a precarious contract (Seifert et al. 2007). Employment strain, a concept developed by Lewchuk, Clarke and colleagues (Clarke et al. 2007), is a structured framework that examines together the effects of the uncertainty of the employment relationship, the effort associated with finding and keeping employment and the support obtained by being employed. The authors examined the health outcomes associated with high employment strain. There is, as well, significant Canadian research on organizational factors contributing to adverse mental health outcomes of workers (Vézina et al. 2004), and on organizational interventions to effectively reduce exposure to these hazards (Harvey et al. 2006; Kling et al. 2009; Vézina 2008).

Nonetheless, while scientific research in Canada on the identification of organizational factors constituting psychosocial hazards is advanced, there is much less research on policy, and few policy makers have addressed these issues by enacting regulatory instruments designed to take up the challenges raised by mental health issues in the workplace with regard to primary prevention, workers' compensation or disability prevention and return to work. Both the prevention and compensation of work-related illness, including mental illness, fall under the exclusive jurisdiction of the provinces, with the exception of the federal government's jurisdiction on the approximately $10 \%$ of the workforce working for federally regulated industries. As such, an understanding of the situation in Canada with regard to regulatory issues requires an analysis of 14 jurisdictions, including the provinces and territories as well as the federal jurisdiction.

This paper reviews legal and policy initiatives in Canada with regard to the protection of workers' mental health, and it examines ways in which law and public policy can indirectly affect workers' mental health, either positively or negatively. The concept of legal initiatives refers to legally binding laws and regulations adopted by the competent regulatory authorities. Policies include both the messages codified in the legislative frameworks and also public policy documents 
and discourse that affect working conditions in Canada. This paper does not purport to address private (management) policies, nor does it aim to provide evaluative research results with regard to public policies.

\section{Legal and Policy Initiatives Designed to Address Psychosocial Hazards}

In the study of regulatory frameworks designed to address occupational health and safety issues, three types of legislation require attention: occupational health and safety laws, workers' compensation and legislation addressing return to work. Occupational health and safety laws, and related statutes, define mechanisms to encourage employers to prevent or reduce exposure to hazards, and set penalties for failure to comply with those requirements. These statutes are usually enforced by labour inspectors. Workers' compensation legislation is designed to provide remedies for workers who are injured or become ill because of exposure to occupational hazards. These same statutes, as well as human rights legislation, address hiring and return-to-work issues for people with disabilities, including non-temporary health problems.

\section{Legal Initiatives to Reduce Psychosocial Hazards in the Workplace}

In Canada, most legislative initiatives explicitly designed to prevent or reduce psychosocial hazards in the workplace are confined to issues of violence and harassment. In some jurisdictions, general requirements in occupational health and safety legislation also apply to the protection of both the physical health and mental health of workers.

\section{Prevention of Occupational Violence}

The International Labour Organization and the World Health Organization both define occupational violence as including, among other things, physical violence, psychological violence and harassment, both discriminatory and psychological (Chappell and Di Martino 2006). Canadian policy makers have used the term in a variety of ways, and workers' protection from these different forms of violence is uneven.

Under common law, or civil law in Quebec, employers may be held vicariously liable for verbal, physical and sexual violence by an employee against another employee (Boothman v. Canada 1993 [harassment]) or a third party (Bazley v. Curry 1999 [sexual assault]), and damages can be claimed against the employer by victims of employee violence under the law of tort, or under human rights legislation, although in some circumstances, such claims by employees against employers and co-workers may be barred by workers' compensation statutes (Béliveau St. Jacques v. Fédération des employées et employés de services publics inc. 1996; University of Saskatchewan v. Workers' Compensation Board of Saskatchewan 2009). The policy considerations behind employers' liability for acts of their employees' violent behaviour include the fair allocation of loss to the risk-creating enterprises and deterrence objectives, as it is posited that economic liability will act as an incentive to employers to prevent the risk of violent behaviour, or at least to minimize and manage it (Bazley $v$. Curry 1999). These economic incentives may be neutralized if the aggressive behaviour engendered by work organization characteristics that are conducive to workplace bullying and violence are subtracted from the domain of tort liability by exclusive remedy provisions of workers' compensation schemes.

Aside from the incentives provided by tort law, the first legislation (other than criminal law) targeting workplace violence was human rights legislation; this has existed in some form or other in every Canadian province for decades and it prohibits discriminatory harassment in the workplace, including sexual harassment. 
Discriminatory harassment is just a small part of occupational violence, and more recently several Canadian jurisdictions have adopted legal frameworks designed to include occupational violence as a hazard needing to be addressed by employers under either occupational health and safety legislation or minimum standards legislation. Some legislative approaches require employers to perform systematic risk assessments to be integrated into prevention programs, while others provide for complaint-based mechanisms. The nature of these initiatives varies significantly from one jurisdiction to the next in terms of the nature of the violence being targeted, the remedies proposed and the types of mandates being delegated to administrative agencies. Development of these legislative requirements has been slow (Pizzino 2002), although more recently most jurisdictions have acknowledged the importance of a regulatory response.

Saskatchewan legislation was the first to address the prevention of occupational violence. In force since 1997, Occupational Health and Safety Regulations (1996) identifies priority sectors in which mandatory violence-prevention policies need to be adopted and prescribes that training should be provided to workers.

\section{Discriminatory harassment is} just a small part of occupational violence.

British Columbia was also one of the first jurisdictions to explicitly target occupational violence in its occupational health and safety regulations (WorkSafeBC 1998), perhaps because occupational violence was early on the subject of scientific attention in that province (Boyd 1995). While acknowledging significant under-reporting of violent incidents, Boyd (1995), in a study based on workers' compen- sation data, showed an increase in violent incidents targeting workers, particularly in healthcare and community organizations.

The BC occupational health and safety regulation (WorkSafeBC 1998: sections 4.24-4.31) provides a restrictive definition of violence, limiting the term to "the attempted or actual exercise of physical force so as to cause injury to a worker" and excluding from the definition acts of physical violence perpetrated by a worker. The regulation labels the following as "improper activity or behaviour": "the attempted or actual exercise by a worker towards another worker of any physical force so as to cause injury, and includes any threatening statement or behaviour which gives the worker reasonable cause to believe he or she is at risk of injury; and, horseplay, practical jokes, unnecessary running or jumping or similar conduct" (WorkSafeBC 1998). While this behaviour is prohibited, it is nonetheless trivialized both by its name and by the lack of requirements with regard to risk assessment to protect workers from internal violence (from within an organization), be it horizontal or vertical. Employers are required to undertake risk assessments with regard to violence but not with regard to "improper activity or behaviour." The risk assessment, which should involve the organization's joint health and safety committee, can lead to a variety of requirements, both in terms of policy and work arrangements designed to either eliminate or minimize the risk to workers, and to ensure that workers report incidents of violence to the Workers' Compensation Board, now WorkSafe BC. No such requirements appear to exist if the violence comes from internal sources.

Manitoba's occupational health and safety regulations of 2006 include provisions that require risk assessments related to physical violence or threats of physical violence (Workplace Health and Safety Regulation 
2006, Part 11) and discriminatory harassment (Workplace Health and Safety Regulation 2006, Part 10). Newfoundland has similar requirements (Occupational Health and Safety Regulations 2009, Part 22).

Recently, in 2008, the federal jurisdiction adopted more detailed and broader provisions in regulations designed to prevent violence that is defined as follows: "work place violence constitutes any action, conduct, threat or gesture of a person towards an employee in their work place that can reasonably be expected to cause harm, injury or illness to that employee" (Canada Occupational Health and Safety Regulations 2007: s. 20.2; "Regulations Amending the Canada Occupational Health and Safety Regulations" 2007, December 15).

\section{Bullying is not explicitly included in the definition of violence but it is explicitly identified as a factor in workplace violence.}

The federal regulation neither restricts the concept of violence to physical violence nor eliminates internal violence from the purview of the prevention process. Although bullying is not explicitly included in the definition of violence, it is explicitly identified in s. 20.3(b) as a factor that contributes to workplace violence; as such, the employer is obliged to "dedicate sufficient attention, resources and time to address" the prevention of bullying and the protection of workers against bullying. Employers are also required, among other things, to assist employees who have been exposed to workplace violence. Detailed provisions circumscribe the nature of the risk assessment required and the nature of the controls that ensue from the assessment. The employer is also required to regularly review the effectiveness of the prevention measures, according to detailed parameters defined in the regulation. The federal regulation does provide for differential treatment of the violent incident depending on whether or not the workplace violence was caused by an employee; the intervention of a "competent person" to investigate the situation is reserved for those cases involving employee aggressors or cases where the aggression from non-employees is not deemed to be a normal condition of employment, as long as the employer already has effective prevention procedures and controls in place. Finally, the regulation requires the training of employees with regard to workplace violence and stipulates the nature of the training and the necessity of regular revision of the training procedures. Prior to the adoption of this legislation, courts and tribunals have upheld workers' rights to refuse to work when doing so would expose them to situations of physical violence (Verville v. Canada [Service Correctionnel] 2004), although it is less clear that the protection of their mental health was an acknowledged justification for refusing to work (Boivin v. Canada [Customs and Revenue Agency] 2003).

In December 2009, Ontario introduced provisions on violence and harassment to the Occupational Health and Safety Act, which came into force on June 15 , 2010. The act addresses both workplace violence and workplace harassment, defined broadly to mean "engaging in a course of vexatious comment or conduct against a worker in a workplace that is known or ought reasonably to be known to be unwelcome" (Occupational Health and Safety Amendment Act [Violence and Harassment in the Workplace] 2009: s. 1). Workplace violence is also defined in that section, and means "the exercise of physical force by a person against a worker, in a workplace, that causes or could cause physical injury to the worker" and also includes a "statement or 
behaviour that it is reasonable for a worker to interpret as a threat to exercise physical force against the worker, in a workplace, that could cause physical injury to the worker." It is of note that the provisions requiring action on behalf of the employer are more exacting with regard to workplace violence.

Requirements pertaining to harassment are more limited than those regarding violence. Harassment prevention is prescribed in s. 32.01, which obliges the employer to prepare and post a written policy (in workplaces with more than five workers regularly employed, unless an inspector orders otherwise); S. 32.0.6 states that the employer must maintain a program to implement the policy, a program that must include measures for reporting incidents of harassment to the supervisor or employer, and sets out how the employer will investigate complaints. Further provisions may be prescribed.

The more exacting requirements regarding risk assessments are restricted to physical workplace violence. Bill 168 does introduce innovative legal language regarding domestic violence, requiring that "if an employer becomes aware, or ought reasonably to be aware, that domestic violence that would likely expose a worker to physical injury may occur in the workplace, the employer shall take every precaution reasonable in the circumstances for the protection of the worker" (Occupational Health and Safety Amendment Act [Violence and Harassment in the Workplace] 2009: s. 32.0.4). The introduction of the issue of domestic violence is particularly important for women: an American review of the literature has shown that many cases of physical violence involving women workers, and up to $10 \%$ of homicides in the workplace, have been attributed to intimate partners and relatives (Santana and Fisher 2002).

Provisions governing the prevention of violence include the obligation to provide information regarding the policy and program and regarding the potential danger of violence, although personal information is limited to that which "is reasonably necessary to protect the worker from physical injury" (Occupational Health and Safety Amendment Act [Violence and Harassment in the Workplace] 2009: s. 32.0.5 [4]). Incidents of violence that lead to the need for medical attention must be reported by the employer within four days of the occurrence; Bill 168, by amending s. 43 of the Occupational Health and Safety Act, allows for a worker's right to refuse to work, or to do particular work, if the worker has reason to believe that "workplace violence is likely to endanger himself or herself" (Occupational Health and Safety Amendment Act [Violence and Harassment in the Workplace] 2009: s. 52). This right is not provided for in cases of harassment that do not give reason to believe there will be physical violence; nor does this right appear to apply in other circumstances that could jeopardize workers' mental health without endangering their physical health (see by analogy Vogan v. Ten Star Financial Services 2009).

Quebec has no explicit legislation governing physical violence in the workplace, although it does have fairly elaborate legislation on psychological harassment, provided for in amendments to minimum standards legislation, introduced in 2002 and in force since 2004 (Act Modifying an Act Respecting Labour Standards 2002). This legislation, the first of its kind in North America, acknowledges the workers' right to a workplace free of psychological harassment and makes employers responsible for preventing workplace harassment. They are obliged to use reasonable means to prevent harassment, and failure to do so can give rise to a complaint to the Commission des normes du travail, or, in the case of unionized workers, a grievance. The definition of psychological harassment is, 
by law, written into all collective agreements and reads as follows, by virtue of s. 81.18 of Labour Standards Act: "any vexatious behaviour in the form of repeated and hostile or unwanted conduct, verbal comments, actions or gestures, that affects an employee's dignity or psychological or physical integrity and that results in a harmful work environment for the employee. A single serious incidence of such behaviour that has a lasting harmful effect on an employee may also constitute psychological harassment". It thus goes beyond the classic definition of psychological harassment in social psychology (Chappell and Di Martino 2006; Einarsen et al, 2011) by including a single serious incident, and parliamentary debates show that this addition sought to cover situations such as those in which a worker immediately withdraws from the workplace because of the severity of the incident (Lippel 2005). Remedies include orders providing for reinstatement of the harassed worker, requiring the employer to undertake reasonable action to put a stop to harassment, and providing for the modification of disciplinary orders and indemnities for loss of employment. The exclusive remedy provisions of workers' compensation legislation apply; so, for those workers who do not suffer health problems because of the harassment, monetary damages can be granted for lost wages, punitive and moral damages and payment for psychological support. Between June 1, 2004, and March 31, 2008, the Commission des normes du travail received 8,631 complaints from non-unionized workers (Dupéré 2009), and although figures for unionized workers are unavailable (because unions themselves are the first respondents to those complaints), there is reason to believe that the number of complaints in unionized workplaces is also very important. As a result of the dual recourse, there is a significant amount of litigation as cases involving the same parties proceed both with regard to workers' compensation claims and under arbitration or adjudication by the Quebec Labour Relations Board (CRT) (Lippel et al. 2009; Cox 2010).

\section{Employers are obliged to use reasonable means to prevent barassment.}

Saskatchewan also enacted legislation specific to psychological harassment, introducing new mechanisms to govern complaints under its occupational health and safety legislation (Occupational Health and Safety Amendment Act [Harassment Prevention] 2007). Several years earlier, Saskatchewan had also included discriminatory harassment as an occupational hazard in its health and safety legislation, thus recognizing harassment as a hazard to health and not simply a violation of human rights. Harassment is defined as follows: "Harassment means any inappropriate conduct, comment, display action or gesture by a person that ... adversely affects the worker's psychological or physical wellbeing and that the person knows or ought reasonably to know would cause a worker to be humiliated or intimidated; and that constitutes a threat to the health of the worker ... To constitute harassment ... repeated conduct, comments, displays, actions or gestures must be established; or a single serious occurrence of conduct, or a single, serious comment, display, action or gesture, that has a lasting, harmful effect on the worker must be established" (Occupational Health and Safety Amendment Act [Harassment Prevention] 2007: s. 2). Again, this definition differs from those used in Quebec and Ontario, notably by requiring evidence of a clearer intention of the author of the harassment to harm the worker. Unlike the definition used in Quebec, it appears to 
exclude situations that affect the dignity but not the health of the worker.

Even in those provinces that do not have explicit legal language on violence and harassment, remedies may be available under occupational health and safety legislation or by virtue of the implicit integration, in collective agreements, of protections drawn from a variety of legislative provisions and other sources. (In Alberta, see for example, with regard to use of physical force against a worker, United Food and Commercial Workers Union, Local 401, v. Canada Saferway [2009]. In Ontario, with regard to harassment, see Amalgamated Transit Union v. Toronto Transit Commission [2004].) Other protective provisions include legislation governing protections for workers who work alone (see, for example, in Prince Edward Island: Occupational Health and Safety Act, General Regulations 1987, Part 53; in Newfoundland: Occupational Health and Safety Regulations 2009, Part 15; in Manitoba: Workplace Health and Safety Regulation 2006, Part 9). Working alone is known as a risk factor for some forms of occupational violence, notably physical (Di Martino et al. 2003) and sexual assault (Santana and Fisher 2002).

The existence of legal requirements to prevent violence and harassment does not guarantee the disappearance of these acts. Nonetheless, legislative interventions in many provinces have been accompanied by publications of prevention manuals and increased interest in the issues targeted by the legislature (Cantin and Cantin 2004; Kreissl et al. 2010; Cox 2010; Lafond and Provencher 2004).

\section{Protection of Workers' Mental Health}

Do occupational health and safety acts protect workers' mental health? While the answer to this question is clearly yes in European countries (Leka et al. 2010), including Great Britain (Cousins et al. 2004), Germany (Paridon et al. 2007), Spain (Moncada et al.
2010) and France (droit.org 2009; Lerouge 2005), as well as in Australia (Guthrie et al. 2010) and New Zealand (Scott-Howman and Walls 2003), in Canada, surprisingly, the answer to this question varies from one jurisdiction to the next. As we have seen in the previous section, the answer is often no notably in Ontario, where the right to refuse work dangerous to a worker's mental health still does not appear to exist.

Saskatchewan explicitly includes mental health in the purview of its Occupational Health and Safety Act and regulations: "For the purposes of the Act and in these regulations and all other regulations made pursuant to the Act, 'injury' includes any disease and any impairment of the physical or mental condition of a person" (Occupational Health and Safety Regulations 1996: s. 2[2]). In Quebec, after years of hesitation, the issue was decided in a significant decision of the Commission des lésions professionnelles (CLP) regarding the right to refuse work because of psychological harassment (Chagnon et Marché Bél-Air inc 2000), a decision that influenced the subsequent hiring and training of labour inspectors employed by the Commission de la santé et de la sécurité du travail (CSST) (Lippel et al. 2010). Employers are still questioning, thus far unsuccessfully, the jurisdiction of labour inspectors with regard to the prevention of mental health problems (Sobey’s Québec inc. et Délég. SST E Co-pres. CSS-Sobeys et C.S.S.T.). In those jurisdictions where mental health falls within the mandate of labour inspectors, there have been several interventions designed to address not only issues of violence but also organizational factors such as electronic monitoring, using headsets, of workers' productivity (Davezies 2008; Lippel et al. 2010) and the effects of downsizing and restructuring (Quinlan 2007).

Research as to strategies to support the labour inspectorate in its mandate to ensure the protection of workers from psychosocial 
hazards is ongoing in Australia and in several Scandinavian countries (Fooks et al. 2007; Saksvik et al. 2007; Johnstone et al. 2010; Rasmussen et al. 2010 ).

\section{Summary}

In summary, some Canadian legislators have slowly come to accept the need for legal mechanisms to promote the prevention of occupational violence, although political will to legislate is more prevalent with regard to physical violence than psychological violence. Several countries have also regulated psychological harassment as an occupational hazard in recent years (Lippel 2010).

Broader prevention issues with regard to workers' mental health are rarely discussed in the context of occupational health and safety law, a situation described with some concern by specialists in the field (Laflamme 2008).

\section{Legal Frameworks Governing Compensation for Work-Related Mental Health Problems}

One possible explanation for the slowness with which Canadian legislators have addressed mental health problems in the workplace is that the costs of these problems are often invisible to the workers' compensation system, and the need for occupational health and safety legislation is often measured by the costs of compensated injury (Cox and Lippel 2008). Access to workers' compensation for mental health problems related to physical injury caused by work or to acutely stressful situations is, at least theoretically, available in every Canadian province, although there are variations between policy approaches (Lippel and Sikka 2010).

When mental health problems arise from chronically stressful working conditions (e.g. harassment, or work reorganization and resulting work intensification), many provinces, including British Columbia, Ontario,
New Brunswick, Newfoundland, Nova Scotia and Manitoba, explicitly exclude these claims (Lippel and Sikka 2010), although recent case law has questioned the constitutional validity of differential treatment that provides fewer protections for the mentally ill (Plesner v. British Columbia [Hydro and Power Authority] 2009). In those provinces where such claims are covered under the law, access to compensation remains difficult (Lippel and Sikka 2010). It is not surprising that occupational health and safety legislation, as we have just seen, includes the protection of workers' mental health in Saskatchewan and Quebec, the first two provinces to accept workers' compensation claims for mental health problems related to chronic stress (Lippel 1990).

Although the costs to workers' compensation systems are relatively minor - accepted claims represent approximately 1\% of claims in Quebec (Commission de la santé et de la sécurité au travail 2008), which has the broadest scope of coverage - costs related to absence associated with mental health problems are of great concern for private insurance companies, and researchers have shed light on the significant cost to both workplaces and individuals of mental health-related absences (Brun and Lamarche 2006; Dewa et al. 2004; Lim et al. 2008) and presenteeism (Biron et al. 2006).

Given that incentives for the prevention of occupational injury are often woven into the financing mechanisms of workers' compensation legislation, by way of experience rating systems, failure to acknowledge the workrelatedness of mental health problems makes these problems invisible to the mechanisms designed to provide economic incentives to drive prevention. This leaves such initiatives to those private insurers who provide (nonmandatory) coverage to workplaces, thus privatizing prevention mechanisms. In the Canadian context, where employment insurance provides for a maximum of 15 weeks of 
support, at $55 \%$ of gross insurable earnings, Canada compares poorly with other countries with regard to social security protections for those unable to work because of illness (Chaussard et al. 2008). In this context, access to workers' compensation benefits for disability related to mental health problems becomes all the more important.

\section{Legal Frameworks and the Promotion of Support for the Return to Work of People with Mental Health Problems}

Two challenges specific to workers with mental health problems are of particular import. First, given the exclusion of the majority of work-related mental health problems from the purview of most workers' compensation legislation in Canada, as we have seen in the previous section, the return-to-work programs integrated into the workers' compensation legislation fail to apply to these workers, leaving them with less protection than workers suffering from physical disability caused by work. Even in those jurisdictions where mental health problems are recognized as occupational injuries or illnesses, as in Quebec, return-towork mechanisms apply with difficulty when the functional limitations associated with the compensated illness require that the worker no longer be exposed to the authors of harassment (Blouin et AFG Industries ltée 2007) or to even moderately stressful working conditions (Bouchard et Breakwater-Mine Bouchard Hébert 2009; Lippel and Cox 2010).

Secondly, there is some discussion as to the effect of legislation aimed at preventing violence and harassment on the equality rights of those seeking employment or seeking to remain in employment or return to employment when they have suffered from a mental illness. Increasingly, we hear of screening techniques designed to remove potentially violent workers (Courcy et al. 2004) but also potentially vulnerable targets from the workplace, a practice that could easily lead to discrimination based on disability under human rights legislation. Employers may find themselves limited in their ability to order a worker to undergo a psychiatric assessment, a recourse that may be deemed to be a violation of the worker's human rights, and they may even be ordered to pay damages to the worker (Greater Vancouver Regional District Employees' Union v. Greater Vancouver Regional District 2007a, 2007b). Similar preoccupations may arise with regard to the obligations of employers, for instance those introduced in Ontario Bill 168, to inform workers of people who may be potentially violent. Privacy protection is addressed in the bill, but the first years of application will determine to what extent the rights to privacy of workers and also patients, welfare recipients and students may be compromised by the obligation of the employer to identify to employees the potentially violent.

Return-to-work mechanisms apply with difficulty when the functional limitations require the worker no longer be exposed to the authors of harassment.

\section{Indirect Consequences of Law and Policy: How Policy Drives Working Conditions That Affect Mental Health}

Regulation of violence and harassment cannot in itself eliminate psychosocial hazards, and a first step to improving prevention is to ensure that the protection of workers' mental health is part of the occupational health and safety mandate (Lippel et al. 2010). Yet even the most far-reaching prevention provisions will not reduce psychosocial hazards if there is no implementation and, worse, if there are actu- 
ally policy incentives to increase exposure to psychosocial hazards. In this section, I illustrate ways in which public policy in Canada has contributed to an increase in the exposure of workers to psychosocial hazards. I look first at cost-saving strategies in the healthcare sector (private and public) and then at cutbacks in the public sector.

\section{Cost-Saving Strategies in the Healthcare Sector}

When provincial or federal governments choose to reduce spending, this has an impact both on the working conditions of those affected and on the quality of care and services provided to the public. This is known to occur not only in Canada but in most countries in the Organisation for Economic Co-operation and Development (OECD), and the link between occupational violence and reductions in quality of public services has been documented internationally (Di Martino et al. 2003).

Mechanisms by which workers are exposed to increased violence in this context were explored in a recent study by Armstrong and colleagues (Armstrong et al. 2009). The survey study examined the working conditions of unionized "direct care" workers, including personal support workers, in long-term care facilities in three Canadian provinces and compared the results with studies from four Nordic countries. The authors compared the prevalence of various conditions of work and several health measures. The survey data were complemented by qualitative data drawn from a variety of sources. The investigators' findings with regard to exposure to violent incidents show that $38 \%$ of Canadian direct care workers (and $43 \%$ of personal support workers) were exposed to actual physical violence on a daily basis. In the Scandinavian countries, only $7 \%$ of comparable workers reported threatened or actual violence on a daily basis. Qualitative data provided information as to the types of conditions that the workers identify as potential causes of the violence. They point to understaffing and the obligation to care for too many residents with insufficient time. They also described a technological change that was introduced to cut costs and that goes far in explaining why normally passive residents may develop aggressive behaviour targeting staff.

In an effort to reduce expenses, institutions have developed policy restricting the use of diapers for incontinent patients. In the words of the authors: "After discussing 'diaper police' and efforts to hide unused diapers, and concluding that they 'don't feel good' about being forced to keep residents in wet diapers, [focus group participants] drew attention to a technological innovation that may serve cost conscious employers in the short run, but certainly does not serve incontinent residents nor those caring for them. In these new diapers, 'there's a line at the top. Once that line changes colour, they're 75 percent.'The technology, not the worker or the resident decides" (Armstrong et al. 2009: 131).

It would be difficult to imagine a clearer illustration of working conditions requiring high demand and providing low control, the category of conditions most risky for workers' mental health in the job strain model. While scientists have documented implications of these hazardous conditions for decades (Karasek 1979), the Armstrong study provides telling evidence that technology can and is being used to make things worse, not better, for both workers and residents. The authors found that $43 \%$ of direct care workers reported finishing the day "almost always" feeling mentally exhausted, compared with $16 \%$ of Swedes, $8 \%$ of Norwegians, $12 \%$ of Finns and $8 \%$ of Danes working in comparable jobs (Armstrong et al. 2009). Not surprisingly, workers in the Nordic countries are far more likely to be employed in conditions associated 
with the "active work organization" category, the most protective category in Karasek's stress-management model of job strain (Karasek 1979; Parent-Thirion et al. 2007).

Other authors have noted the effect of cost-cutting in the healthcare sector on the behaviour of patients and the vulnerability of workers to client-generated violence, both in Canada (Pizzino 2002) and internationally (Chappell and Di Martino 2006).

\section{Cutbacks in the Public Sector}

Restructuring (Quinlan and Bohle 2009) and privatization (Virtanen et al. 2010) have been shown to increase the ill health of workers affected by the changes, and bullying is known to increase in the context of job insecurity (Baillen and De Witte 2009). Case law from workers' compensation appeals in Quebec, one of the few Canadian provinces to provide compensation for mental health problems related to non-acute psychosocial hazards (Lippel and Sikka 2010), provides illustrations of mechanisms by which cutbacks in the federal and provincial public sectors directly contributed to exposing workers to unusually stressful working conditions. These examples illustrate different dimensions of exposure to psychosocial hazards.

Between 1995 and 1998, the federal government restructured the public service, drastically reducing the number of employees. Restructuring was implemented over a 15-month period in employment insurance offices. As a result, workers became ill. Three workers successfully claimed workers' compensation benefits after being diagnosed with work disability due to adaptation disorders and depression (Boivin, Sansfaçon et Blackburn et D.R.H.C. Direction Travail 2001). The appeal tribunal, the CLP, accepted the claims, stipulating that they were covered under both the occupational disease and the work accident provisions of the Government Employees
Compensation Act and the relevant Quebec legislative provisions (R.S.C. 1985, c. G-5; this act refers to Quebec legislation on workers' compensation when claimants work in Quebec, thus incorporating provisions of the Act Respecting Industrial Accidents and Occupational Diseases). The evidence showed how the team of workers was reduced from 60 to 11 over 15 months. Workload was described as untenable because the number of clients was not reduced, and the clients became impatient and aggressive because of the inadequacy of the service provided. Among the positions to be abolished was that of the receptionist, so no buffer existed between clients and employees doing the interviews, waiting times were important and caseloads (between 25 and 40 employment insurance claimants were interviewed each day by the workers who fell ill) were excessive.

Similar increases in workloads of federal public sector workers led to the acceptance of other claims. That of a front-line worker in payroll was accepted both because of the reduction in staff that led to the increase in workload and also because of the job description, which was found to be telling with regard to the employer's expectations:

"15. The job holder must constantly deal with employees, colleagues and supervisors who are stressed, insecure, discouraged, depressed, angry or hostile and also deal with conflicting priorities from supervisors, employees, and HR professionals, while continuing to fulfil a large variety of urgent tasks requiring concentration. This task becomes more and more demanding as work demands and related problems, as well as interruptions, increase. On average, the payroll counsellor spends half her time doing calculations and half her time dealing with clients. 
16. Stress resulting from the need to balance conflicting priorities, with difficult employees and clients and with heavy work load and short and non-negotiable deadlines may lead to burn out, which may require medical care and lead to work absence" (Laflamme et DRHC travail 2000: paragraphs 61 and 62 [our translation]).

A claim by a food inspection professional was accepted despite the fact that her hours of work were not actually increased. Her workload and responsibilities were found to have doubled as a result of a decrease in staff, and the increased workload was found to be an occupational hazard that justified the acceptance of her claim for an occupational disease (depression) (Belleau and Agence Canadienne d'Inspection des aliments DRHC-Direction Travail et CSST 2003).

Provincially, cutbacks in the healthcare sector have led to several accepted claims, including those that illustrate the mechanisms by which work reorganization and job insecurity can be associated with bullying and harassment, as shown in the literature (Baillen and De Witte 2009). In one example, a nurse who had worked for 23 years in the long-term care facility of a local hospital "bumped" (replaced because of higher seniority) a younger nurse in the operating room (OR) after the long-term care facility was closed. The physicians in charge of the OR, and other personnel, resented the arrival of a 55-year-old nurse to replace the younger nurse, whom they had trained and had hoped to keep as part of the OR team for a long time. The worker was the object of social exclusion and was provided little or no training; the team leader refused to communicate with her and she was the object of hostility coming from both physicians and colleagues. The team leader testified that no one wanted to train the worker because the doctors disapproved of her presence and no one wanted to have the doctors "on their backs." A colleague testified that when he attempted to provide her with some training, he was the subject of rejection by the rest of the team. The employer failed to provide support in this context, letting the situation deteriorate over a period of months. The factual situation predated Quebec's psychological harassment legislation, but in accepting the claim, the tribunal did conclude, perhaps surprisingly, that the worker was not a victim of harassment; nonetheless, the working conditions to which the worker was subjected were held to go beyond normal working conditions and her claim was accepted (Langlais et Centre hospitalier de Chandler 2006).

Restructuring in the Quebec healthcare sector also provided an illustration of what the tribunal described as "adaptation overdose," a consequence of workers being continually required to adapt to new situations (Plouffe-Leblanc et C.H.U.S. - Hôpital Fleurimont 2003). The tribunal concluded that the worker, who had been required to change her position within the hospital seven times in six years in the context of continual restructuring, was suffering from an occupational disease (situational depression) attributable to adaptation overdose. Her depression was actually triggered when she made a mistake in the administration of a vaccine to a child, and recommended to the mother to file a complaint, after which she felt torn between her professional responsibilities and her allegiance to her employer and colleagues. However, it was the cumulative exposure to change, involving important responsibilities and inadequate training, that led the tribunal to find in favour of the worker. She was a nurse who had had 17 years' seniority in the same department, which was then closed. She was subsequently required to work in seven different outpatient clinics over a course of six years, each requiring training that was 
not necessarily provided, and, by the second year, she was required to train others, often without manuals or written protocols. The CLP, in concluding in favour of the worker, subscribed to the premise that restructuring is a management prerogative that is a normal working condition in the modern workplace. Nonetheless, in light of the factual and medical evidence the tribunal concluded that the working conditions to which the worker was subjected went beyond what can normally be expected in a workplace.

\section{Conclusion}

Legislative frameworks designed to protect workers' mental health and to provide them with economic and social support when they are disabled with mental health problems attributable to work take many forms. Their existence, or their absence, is a variable that needs to be considered in research, and their crafting needs to be carefully addressed by those responsible for public policy.

Access to non-stigmatizing economic support for those who are unemployed has been shown to be protective for the mental health of workers; however, those who need to have recourse to means-tested welfare programs see their mental health adversely affected (Rodriguez et al. 2001). This leads to the belief that depriving workers of workers' compensation for mental health problems attributable to non-acute stressful situations actually contributes to workers' mental ill health.

The existence of anti-violence legislation, including anti-harassment legislation, will influence workers' and employers' awareness of these phenomena, and will thus contribute to prevention. Increased awareness will also be reflected in higher reported prevalence; yet awareness is an essential step in the process of addressing occupational violence (Chappell and Di Martino 2006). When organizational culture suggests that exposure to violence is part of the job (Pizzino 2002), reported prevalence of violent acts may be far lower than in workplaces with good prevention programs, as the first step to prevention is the rejection of violence as "normal." Compensation boards that see some types of violence at work as normal (Laprise 2003; Lippel and Sikka 2010) suggest to employers and workers that violence in these contexts is somehow acceptable, a strategy that does little to prevent the health consequences of continual exposure to violence.

\section{Access to non-stigmatizing economic support for those who are unemployed has been shown to be protective for the mental bealth of workers.}

Similar concerns arise when physical violence is trivialized when perpetrators are members of the organization, be they employees or supervisors. This having been said, it is important to recall that in Canada, $17 \%$ of all violent criminal victimization occurs in the workplace, yet only $12 \%$ of those cases involve a co-worker as the perpetrator (de Léséleuc 2004).

Violence is a significant source of mental health problems for workers (Commission de la santé et de la sécurité au travail 2009), as is psychological harassment (Dupéré 2009); and, as the legislative overview above shows, violence is often the first psychosocial hazard to be addressed by Canadian regulators. Yet many other working conditions, if left unchecked, will undermine workers' mental health - it's not enough to act on issues of violence while leaving aside other psychosocial hazards that, in the long run, may prove to be equally or even more deleterious than physical violence. Mandatory risk assess- 
ments for the identification of all psychosocial hazards in the workplace exist in several countries (Johnstone et al. 2009; Leka et al. 2010; Rasmussen et al. 2010; Bruhn and Frick, 2010), yet they are not required in most Canadian jurisdictions. National surveillance tools look at the mental health of Canadians, but nationally none gather information specifically on many organizational factors potentially contributing to workers' mental ill health (Dollard et al. 2007). Given the importance of mental health problems in the Canadian workforce (Gilmour and Patten 2007; Patten and Juby 2008), it is time we considered regulatory and policy strategies to reduce the exposures of Canadian workers to psychosocial hazards.

\section{Compensation boards that see} some types of violence as normal suggest that violence in these context is acceptable.

\section{Acknowledgements}

The author acknowledges the support of the Global Health Research Initiative, through its funding of the Teasdale-Corti project Research, Policy and Practice with Regard to Work-Related Mental Health Problems in Chile: A Gender Perspective; and the Social Science and Humanities Research Council of Canada for its support of the Canada research chair in occupational health and safety law.

\section{References}

Act Modifying an Act Respecting Labour Standards. 2002. L.Q. c. 80.

Act Respecting Industrial Accidents and Occupational Diseases. R.S.Q. c. A-3.001.

Amalgamated Transit Union v. Toronto Transit Commission. 2004. In Lancaster's Labour Arbitration News 40 (11/12).
Armstrong, P., A. Banerjee, M. Szebehely, H. Armstrong, T. Daly and S. Lafrance. 2009. They Deserve Better: The Long-Term Care Experience in Canada and Scandinavia. Ottawa, ON: Canadian Centre for Policy Alternatives.

Baillen, E. and H. De Witte. 2009. "Why Is Organizational Change Related to Workplace Bullying? Role Conflict and Job Insecurity as Mediators." Economic and Industrial Democracy 30(3): 348-71.

Bazley v. Curry. 1999. 2 S.C.R. 534.

Béliveau St. Jacques v. Fédération des employées et employés de services publics inc. 1996. 2 S.C.R. 345.

Belleau and Agence Canadienne d'Inspection des aliments DRHC-Direction Travail et CSST. 2003. AZ-50181113 (CLP).

Biron, C., J.-P. Brun, H. Ivers and C.L. Cooper. 2006. "At Work but Ill: Psychosocial Work Environment and Well-Being Determinants of Presenteeism Propensity." Journal of Public Mental Health 5(4): 26-37.

Blouin et AFG Industries ltée. 2007. C.L.P. 11, 2007 QCCLP 2577.

Boivin v. Canada (Customs and Revenue Agency). 2003. PSSRB 94 (CanLII).

Boivin, Sansfaçon et Blackburn et D.R.H.C. Direction Travail. 2001. AZ-01300852 (CLP).

Boothman v. Canada. 1993. 3 F.C. 381 (TD).

Bouchard et Breakwater-Mine Bouchard Hébert. 2009. No. AZ-50552804 (C.L.P.).

Boyd, N. 1995. "Violence in the Workplace in British Columbia: A Preliminary Investigation." Canadian Journal of Criminology 31: 491-519.

Bruhn, A. and K. Frick. 2010. "Why it was so difficult to develop new methods to inspect work organization and psychosocial risks in Sweden". Safety Sci. doi:10.1016/j.ssci.2010.07.011

Brun, J.-P. and C. Lamarche. 2006. Évaluation des coûts du stress au travail. Québec, QC: Chair in Occupational Health and Safety Management. Canada Occupational Health and Safety Regulations. 2007. SOR 86/304.

Cantin, I. and J.-M. Cantin. 2004. Politiques contre le harcèlement au travail et réflexions sur le harcèlement psychologique. Cowansville, QC: Éditions Yvon Blais.

Chagnon et Marché Bél-Air inc. 2000. C.L.P. 388.

Chappell, D. and V. Di Martino. 2006. Violence at Work (3rd ed.). Geneva, Switzerland: International Labour Office. 
Chaussard, M., M. Gerecke and J. Heymann. 2008. The Work Equity Canada Index. Montreal, QC: Institute for Health and Social Policy, McGill University.

Clarke, M., W. Lewchuk, A. de Wolff and A. King. 2007. "This Just Isn't Sustainable': Precarious Employment, Stress and Workers' Health."

International Journal of Law and Psychiatry 30(4-5): $311-26$.

Commission de la santé et de la sécurité au travail. 2008. Rapport annuel de gestion, 2007. QC: Québec Author.

Commission de la santé et de la sécurité au travail. 2009. Statistiques sur les lésions attribuables à la violence en milieu de travail 2004-2007. QC: Québec Author. Courcy, F., A. Savoie and L. Brunet. 2004. Violences au travail: Diagnostic et Prévention. Montreal, QC: Les Presses de l'Université de Montréal.

Cousins, R., C.J. Mackay, S.D. Clarke, C. Kelly, P.J. Kelly and R.H. McCaig. 2004. "Management Standards' and Work-Related Stress in the UK: Practical Development." Work and Stress 18(2): 113-36.

Cox, R. 2010. "Psychological Harassment Legislation in Québec: The First Five Years." Comparative Labor Law And Policy Journal 32 (1): 55-89.

Cox, R. and K. Lippel. 2008. "Falling through the Legal Cracks: The Pitfalls of Using Workers' Compensation Data as Indicators of Work-Related Injuries and Illnesses." Policy and Practice in Health and Safety 6(2): 9-30.

Davezies, P. 2008. Enjeux de santé liés à l'utilisation de la commande vocale sur les plates-formes logistiques (Enquête exploratoire). Lyon, France: Institut Universitaire de Médecine et Santé au Travail.

de Léséleuc, S. 2004. Criminal Victimization in the Workplace (Catalogue No. 85F0033MIF). Ottawa, ON: Statistics Canada.

Dewa, C., A. Lesage, P. Goering and M. Caveen. 2004. "Nature and Prevalence of Mental Illness in the Workplace." Healthcare Papers 5(2): 12-25.

Di Martino, V., H. Hoel and C. Cooper. 2003. Preventing Violence and Harassment in the Workplace. Dublin, Ireland: European Foundation for the Improvement of Living and Working Conditions.

Dollard, M., N. Skinner, M. Tuckey and T. Bailey. 2007. "National Surveillance of Psychosocial Risk Factors in the Workplace: An International Overview." Work and Stress 21(1): 1-29.

droit.org. 2009. Arrêté du 23 avril 2009 portant extension d'un accord national interprofessionnel sur le stress au travail. Author. Retrieved July 3, 2009. <http://textes. droit.org/JORF/2009/05/06/0105/0090/>.
Dupéré, C. 2009. "Pour en connaître davantage sur les personnes ayant porté plainte pour harcèlement psychologique à la Commission des normes du travail." Regards sur le travail 5(2): 40-45.

Einarsen, S., et al. "The Concept of Bullying and Harassment at Work: The European Tradition." In S. Einarsen and H.Hoel, eds., Bullying and Harassment in the Workplace: Developments in Theory, Research and Practice. Boca Raton, FL: CRC Press.

European Agency for Safety and Health at Work. 2007. Expert Forecast on Emerging Psychosocial Risks Related to Occupational Safety and Health (No. 5). Brussels, Belgium: Author.

Fooks, D.G., D. Bergman and B. Rigby. 2007. International Comparison of (a) Techniques Used by State Bodies to Obtain Compliance with Health and Safety Law and Accountability for Administrative and Criminal Offences and (b) Sentences for Criminal Offences

(Research Report No. RR607). London, England: Centre for Corporate Accountability for the Health and Safety Executive.

Gilmour, H. and S.B. Patten. 2007. "La dépression au travail." L'emploi et le revenu en perspective 19(4): 63-76.

Greater Vancouver Regional District Employees' Union v. Greater Vancouver Regional District. 2007a. B.C.C.A.A.A. No. 12 (QL).

Greater Vancouver Regional District Employees' Union v. Greater Vancouver Regional District. 2007b. B.C.C.A.A.A. No. 116 (QL).

Guthrie, R., M. Ciccarelli and A. Babic. 2010. "Work-Related Stress in Australia: The Effects of Legislative Interventions and the Cost of Treatment." International Journal of Law and Psychiatry 33: 101-15.

Harvey, S., F. Courcy, A. Petit, J. Hudon, M. Teed, O. Loiselle et al. 2006. Interventions organisationnelles et santé psychologique au travail. Montréal, QC: Institut de recherche Robert-Sauvé en santé et en sécurité du travail.

Johnstone, R., M. Quinlan and M. McNamara. 2009. "Australian Health and Safety Inspectors' Perceptions and Actions in Relation to Changed Work Arrangements." Journal of Industrial Relations 51(4): 559-76.

Johnstone, R., M. Quinlan and M. McNamara. 2010. "OHS Inspectors and Psychosocial Risk Factors: Evidence from Australia." Safety Sci. doi:10.1016/j. ssci.2010.09.016

Karasek, R.A., Jr. 1979. “Job Demands, Job Decision Latitude, and Mental Strain: Implications for Job Redesign." Administrative Science Quarterly 24: 285-308. 
Kling, R., A. Yassi, E. Smalles, C.Y. Lovato and M. Koehoorn. 2009. "Characterizing Violence in Health Care in British Columbia." Journal of Advanced Nursing 65(8): 1655-63.

Kreissl, B., A. Treash and J. Lutz. 2010. Bill 168 Implementation Guide. Toronto, ON: Carswell.

Labour Standards Act, R.S.Q. c. N-1.1.

Laflamme et DRHC travail. 2000. AZ-00304080 (CLP).

Laflamme, A.-M. 2008. Droit à la protection de la santé mentale au travail. Cowansville, QC: Éditions Yvon Blais.

Lafond, R. and J. Provencher. 2004. Le harcèlement psychologique : tout ce que l'employeur doit savoir. Cowansville, QC: Éditions Yvon Blais.

Langlais et Centre hospitalier de Chandler. 2006. C.L.P.E. 2006LP-102.

Laprise, F. 2003. "Lindemnisation du stress posttraumatique dans un milieu de travail «prévisiblement» violent." In Barreau du Québec (éd). Développements récents en droit de la santé et de la sécurité du travail, 2003. Cowansville, QC: Les Éditions Yvon Blais Inc.

Leka, S., A. Jain, S. Iavicoli, M. Vartia and M. Ertel. 2010. "The Role of Policy for the Management of Psychosocial Risks at the Workplace in the European Union." Safety Science. doi: 10.1016/j.ssci.2010.02.002.

Lerouge, L. 2005. La reconnaissance d'un droit à la protection de la santé mentale au travail (Vol. 40). Paris: L.G.D.J.

Lim, K.-L., P. Jacobs, A. Ohinmaa, D. Schopfiocher and C. Dewa. 2008. "Une nouvelle mesure, fondée sur la population, du fardeau économique de la maladie mentale au Canada." Maladie chronique au Canada 28(3): 103-10.

Lippel, K. 1990. “Compensation for Mental-Mental Claims under Canadian Law." Behavioral Sciences and the Law 8: 375-98.

Lippel, K. 2005. "Le harcèlement psychologique au travail : portrait des recours juridiques au Québec et des décisions rendues par la Commission des lésions professionnelles." Revue Pistes 7(3). Retrieved May 31, 2010. <http://www.pistes.uqam.ca/v7n3/articles/ v7n3a13.htm>.

Lippel, K. 2010. "The Law of Workplace Bullying: An International Overview". Comparative Labor Law And Policy Journal 32 (1): 1-13.

Lippel, K. and A. Sikka. 2010. "Access to Workers' Compensation Benefits and Other Legal Protections for Work-Related Mental Health Problems: A Canadian Overview." Canadian Journal of Public Health 101(Suppl. 1): S16-22.
Lippel, K., M. Vézina and R. Cox. 2010. "Protection of Workers' Mental Health in Québec : Do General Duty Clauses Allow Labour Inspectors to Do Their Job?" Safety Science. doi: 10.1016/j.ssci.2010.04.011.

Lippel, K. and R. Cox. 2010. "Droit de la santé au travail régissant les problèmes de santé mentale: prévention, indemnisation et réadaptation.” In K. Lippel and G. Vallée, eds., JurisClasseur Québec, coll. «Droit du Travail» (Vol. 2, fasc. 27). Montréal, QC: Lexis Nexis.

Lippel, K., R. Cox and I. Aubé. 2009. "Interdiction du harcèlement et protection de la vie privée et des droits fondamentaux." In G. Vallée and K. Lippel, eds., JurisClasseur Québec, coll. «Droit du Travail» (Vol. 1, fasc. 23). Montréal, QC: LexisNexis Canada.

Moncada, S., C. Llorens, N. Moreno, F. Rodrigo and P. Landsbergis. 2010. CC.OO. ("Comisiones Obreras") - ISTAS (Union Institute of Work, Environment and Health) Participatory Action Plan for a Healthier Work Organization: A Case Study. Safety Science. doi: 10.1016/j.ssci.2010.03.014.

Occupational Health and Safety Act. General Regulations 1987. P.E.I. Reg. EC180/87. Occupational Health and Safety Amendment Act (Harassment Prevention). 2007 S.S. c. 34.

Occupational Health and Safety Amendment Act (Violence and Harassment in the Workplace). 2009. S.O. c. 23 (Bill 168).

Occupational Health and Safety Regulations. 1996. R.R. S., C. O-1.1. Reg 1.

Occupational Health and Safety Regulations. 2009. N.L.R. 70/09.

Parent-Thirion, A., E.F. Macías, J. Hurley and G. Vermeylen. 2007. Fourth European Working Conditions Survey (No. EF/06/98/FR). European Foundation for the Improvement of Living and Working Conditions. Accessed April 14, 2011. <www.eurofound.europa. $\mathrm{eu}>$.

Paridon, H.M., C.M. Paridon and F.A. Bindzius. 2007. "The German Berufsgenossenschaften (Institutions for Statutory Accident Insurance and Prevention): Organisation, Mandate and Activities in the Area of Mental Health." International Journal of Law and Psychiatry 30(5-6): 400-15.

Patten, S. and H. Juby. 2008. Profil de la dépression clinique au Canada. Ottawa, ON: Statistics Canada.

Pizzino, A. 2002. "Dealing with Violence in the Workplace: The Experience of Canadian Unions." In M. Gill, B. Fisher and V. Bowie, eds., Violence at Work: Causes, Patterns and Prevention. Devon, United Kingdom: Willan Publishing. 
Plesner v. British Columbia (Hydro and Power Authority). 2009. B.C.J. No. 856.

Plouffe-Leblanc et C.H.U.S. - Hôpital Fleurimont. 2003. C.L.P.E. 2003LP-97.

Quinlan, M. 2007. "Organisational Restructuring/ Downsizing, OHS Regulation and Worker Health and Wellbeing." International Journal of Law and Psychiatry 30(4-5): 385-99.

Quinlan, M., C. Mayhew and P. Bohle, 2001. "The Global Expansion of Precarious Employment, Work Disorganization, and Consequences for Occupational Health: A Review of Recent Research" International Journal of Health Services 31(2): 335-414.

Quinlan, M. and P. Bohle. 2009. "Overstretched and Unreciprocated Commitment: Reviewing Research on the Occupational Health and Safety Effects of Downsizing and Job Insecurity." International Journal of Health Services 39(1): 1-44.

Rasmussen, M.B., T. Hansen, K. T. Nielsen. 2010. "New tools and strategies for the inspection of the psychosocial working environment: The experience of the Danish Working Environment Authority" Safety Science. doi:10.1016/j.ssci.2010.06.002

"Regulations Amending the Canada Occupational Health and Safety Regulations." 2007, December 15. Canada Gazette (Vol. 141, No. 50). Ottawa, ON: Government of Canada.

Rodriguez, E., E. Frongillo and P. Chandra. 2001. "Do Social Programs Contribute to Mental WellBeing? The Long Term Impact of Unemployment on Depression in the United States." International Journal of Epidemiology 30: 163-70.

Saksvik, P.O., S.D. Tvedt, K. Nytro, G.R. Andersen, T.K. Andersen, M.P. Buvik et al. 2007. "Developing Criteria for Healthy Organizational Change." Work and Stress 21(3): 243-63.

Santana, S. and B. Fisher. 2002. "Workplace Violence in the USA: Are There Gender Differences?” In M. Gill, B. Fisher and V. Bowie, eds., Violence at Work: Causes, Patterns and Prevention. Devon, United Kingdom: Willan Publishing.

Scott-Howman, A. and C. Walls. 2003. Workplace Stress in New Zealand. Wellington, New Zealand: Brookers, Ltd.

Seifert, A.M., K. Messing, J. Riel and C. Chatigny. 2007. "Precarious Employment Conditions Affect Work Content in Education and Social Work: Results of Work Analyses." International Journal of Law and Psychiatry 30(5-6): 299-310.

Sobey's Québec inc. et Délég. SST E Co-pres. CSS-Sobeys et C.S.S.T., 2010 QCCLP 3353, April 20th, 2010, confirmed in review (C.L.P.), 364943-71-0812-R et

\section{2-71-0904-R.}

United Food and Commercial Workers Union, Local 401, v. Canada Safeway. 2009. A.G.A.A. No. 1 (Q.L.).

University of Saskatchewan v. Workers' Compensation Board of Saskatchewan. 2009. SKCA 17.

Verville v. Canada (Service Correctionnel). 2004. FC 767 (CanLII).

Vézina, M. 2008. "La prévention des problèmes de santé psychologique liés au travail: nouveau défi pour la santé publique." Santé publique 20(3): S1-S7.

Vézina, M., R. Bourbonnais, C. Brisson and L. Trudel. 2004. "Workplace Prevention and Promotion Strategies." Healthcare Papers 5(2): 32-44.

Virtanen, M., M. Kivimaki, A. Singh-Manoux, D. Gimeno, M.J. Shipley, J. Vahtera et al. 2010. "Work Disability following Major Organisational Change: The Whitehall II Study." Journal of Epidemiology and Community Health 64(5): 461-64.

Vogan v. Ten Star Financial Services, Ontario Labour Relations Board. 2009. 3041-08-OH, June 3, 2009.

Workplace Health and Safety Regulation. 2006. C.C.S.M. c. W 210/ Regulation 217/2006.

WorkSafeBC, 1998. Occupational Health and Safety Regulation: Core Requirements, Improper Behaviour; Violence. Vancouver, BC: Author.

World Health Organization. 2007, May. Plan of Action. Plan endorsed by the World Health Assembly, Geneva, Switzerland. 